\title{
The use of soy protein isolate in meatballs and its effect on the quality and shelf life of the product
}

\author{
Joko Hermanianto, Dhita Sari Siregar *, Nugraha Edhi Suyatma
}

Food Science and Technology Department of IPB University, Indonesia

\section{Abstract}

Beef meatballs are in great demand by the public because of their nonporous texture, juicy, and chewy characteristics, as well as their ability to be stable at cooking temperatures with a long shelf life. The use of Isolated Soy Protein (ISP) shapes the character of meatballs because of its functional properties, including good water holding capacity and emulsion stability formation in a mixture of processed meat products. This research aims to technically determine the multiple emulsion properties of ISP at doses of $0 \%$, $2 \%, 4 \%$, and $8 \%$ and obtain a meatball formulation with a long shelf life that suits the target consumer. The tests include the ISP emulsification, meatball peel formation, product stability, Arrhenius shelf life method, and the sensory evaluation of the hedonic test. Subsequently, data were processed in a completely randomized $1 \times 5$ and a $4 \times 3$ factorial design using SPSS. The emulsification properties of ISP were determined by producing OE (Oil Emulsion) and PG (Purine Gel). Furthermore, ISP was discovered to change the percentage of meat consumed by approximately $2 \%$ as the characteristics of meatball products desired by consumers were achieved. The best formulation of meatballs was achieved with $2 \%$ dry ISP in the first mixing and was conducted at a boiling point of $65^{\circ} \mathrm{C}$.

\section{Article History}

Received May 31, 2021

Accepted June 24, 2021

\section{Keyword}

Beef meatballs, Soybean protein Isolate, ISP emulsification test, RAL, Arrhenius shelf life

\section{Introduction}

Meatballs are a traditional food favored by the Indonesian people (1) with an increasingly high demand yearly (2). These products are also considered highly nutritious (3) and are produced from beef and other livestock, which are then made into round shapes at the first mixing process (4). The meatball's quality is largely determined by its composition, including meat, preservatives, and flour (filler) (5). Furthermore this research focuses on the panelist preference parameter, which affects the product's success in the market. Sensory attributes are a collection of data that describes the character of the food product. Consequently, the meatballs attributes enjoyed by Indonesian consumers include a nonporous, juicy, and chewy texture, along with stability at cooking temperatures, and a long shelf-life. (6). In this research, furthermore, knuckle meat with little fat content was used to obtain a non-porous sensory characteristic (7) due to the tendency of fat to melt at boiling temperature and increase porosity. Meanwhile, the juicy character of the meatball products is brought about by the amount of stored water from inspecting the first boiling process for the right temperature. 
Conversely, springiness is obtained from the use of multiple ISP (8). Previous research shows that ISP is generally used in processed meat formulations that require emulsification stability, such as sausages, burgers, and smoked beef. (9)

Also, Sodium Tripolyphosphate (STPP) is used to maintain emulsion stability (10) due to the formation of cross-links with starch molecules (11). Elasticity is a character obtained from a high protein content of approximately $90 \%(12,13)$. Meanwhile, tapioca flour increases product elasticity because of its good adhesion induced by higher amylopectin content in comparison to amylose (14). BTM are food additives, which are safe (15) at a maximum use dose of $0.30 \%$ meat weight (16). Furthermore, due to the high water holding capacity (WHC), emulsion, and gelation power of ISP, it is used to obtain meatballs that are stable while boiling. Therefore, products with high WHC are stable at cooking temperatures and have a longer shelf life. The existence of a Standard Operating Procedure (SOP) is important in creating quality meatballs (17), where the production flow charts are carefully considered in detail as a reference for product quality standards. Therefore, this research aims to technically determine the multiple emulsification properties of ISP and obtain a meatball formulation with a long product shelf life suitable for the target consumer.

\section{Research Methods}

\subsection{Research time}

This research was conducted in 3 months between October and December 2020 at PT $\mathrm{XYZ}$.

\subsection{Research time}

The materials included $5^{\circ} \mathrm{C}$ ice water, beef, salt, STPP, beef-flavored broth, white pepper, fresh garlic, and 5 types of ISP with an average protein content of $90 \%$ found in COA. Also, the required tools included trained panelists, bowl cutters, thermometer probe, meatball printing machine, texture analyzer machine with a blunt needle, boiling bowl with a thermometer, showcase chiller, incubator, and UF110 Memmert type oven. The IBM SPSS 22 operating system and the tiered shelf life method were used. Subsequently, Arrhenius, Anova, and Duncan Advanced tests were conducted with 3 replications using SPSS twice on a $1 \times 5$ RAL and $4 \times 3$ Full Factorial RAL.

\subsection{Research procedure}

This research was divided into 2 stages:

\subsubsection{First research.}

\subsubsection{Emulsification test.}

i. 5 ISP formulations were made into the Oil Emulsion (OE) at a dosage ratio of ISP:oil:water $=1: 5: 4$, using a bowl cutter of 2500 RPM minimum speed and stored for $1 \times 24$ hours in a cool temperature. The parameters of stickiness, aroma, and elasticity were observed by trained panelists. Then, the experimental 1x5 design data with 3 replications was calculated by SPSS using the Anova and Duncan's advanced test (18). Subsequently, 3 emulsified ISP were obtained to continue the meatballs production process. 
ii. 5 ISP formulations were made into Purine Gel (PG) at a dosage ratio of ISP: water = 1:4, using a bowl cutter of 2500 RPM minimum speed and stored for $1 \times 24$ hours in a cool temperature. The parameters of stickiness, aroma, and elasticity were observed by trained panelists. Then, the experimental $1 \times 5$ design data with 3 replications was calculated by SPSS using the Anova and Duncan's advanced test. Subsequently, 3 emulsified ISP were obtained to continue the meatballs production process.

\subsubsection{The meatball peel formation test}

The control (A1B1) and the other 11 meatballs (A1B2-A3B4) were produced at the first boiling process at 65,75 , and $85^{\circ} \mathrm{C}$

Flowchart of making control meatballs:

The frozen knuckles were thawed quickly, the meat chopped and then weighed along with other ingredients, such as tapioca flour, salt, STPP, and seasoning, which consisted of fresh garlic, white pepper powder, and beef-flavored broth (19). Subsequently, mix the ingredients in a bowl cutter with the steps in Figure 1:

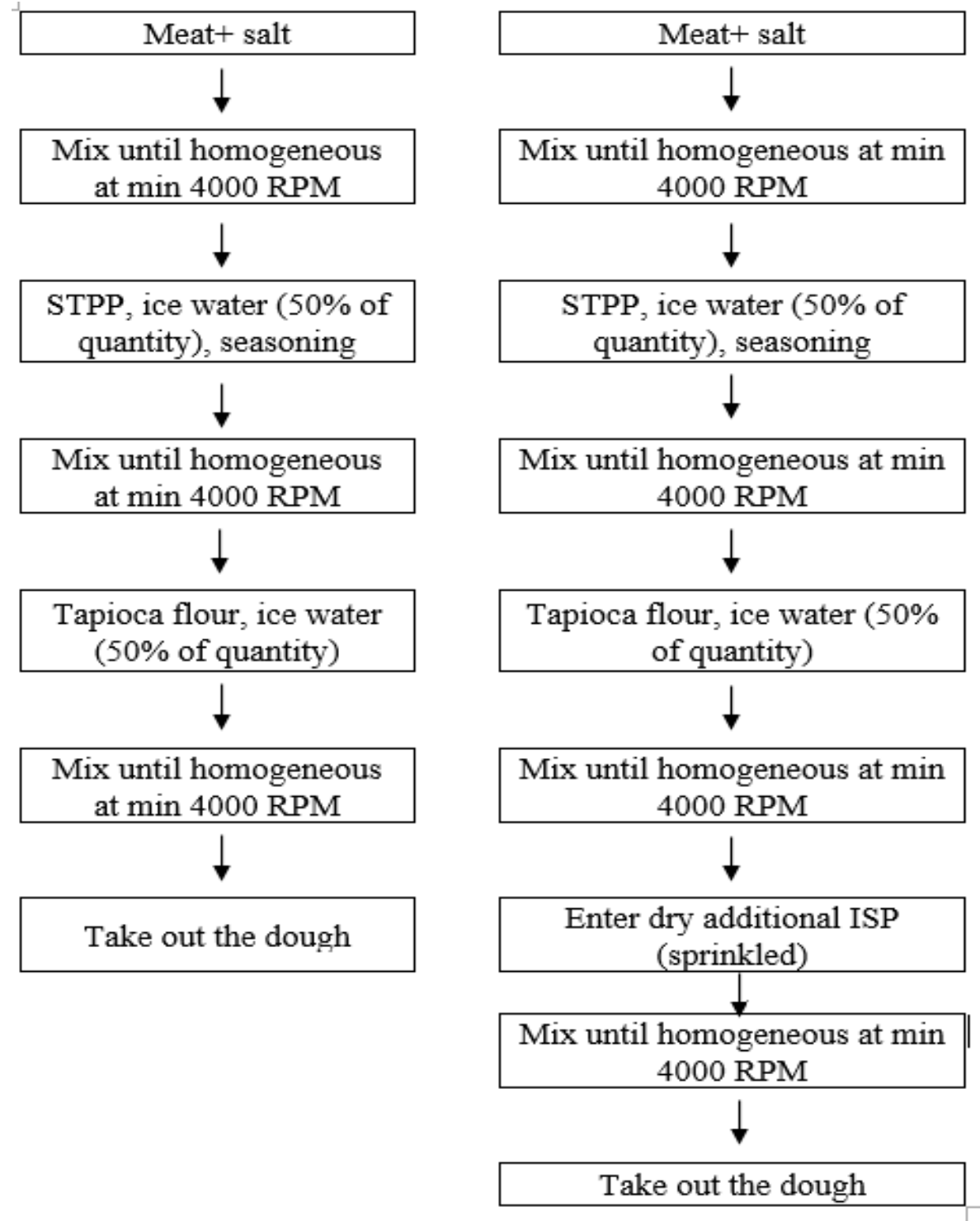




\subsubsection{Stability test of the 12 types of meatballs (A1B4-A3B4):}

i. Inflate power

At $120^{\circ} \mathrm{C}$ for 180 seconds

Dk = (Dak - Daw $) \times 100 \%$

Dk $\quad=$ Inflate power

$\mathrm{d}_{\mathrm{ak}} \quad=$ final diameter

$\mathrm{d}_{\mathrm{aw}}=$ initial diameter

ii. Wrinkle power

At temperatures of $5,15,25,35$, and $45^{\circ} \mathrm{C}$

$D_{\mathrm{kr}} \quad=($ bak - baw $) \times 100 \%$

$D_{k r}=$ wrinkle power

$b_{\mathrm{ak}}=$ final weight

$b_{\text {aw }}=$ initial weight

iii. Crack power

This was performed until the meatballs cracked

iv. Texture Analyzer

Until it cracks using a texture analyzer machine with a blunt needle tip (Kusnadi et al., 2012).

v. Elasticity

The texture analyzer engine graphics start and end within seconds.

vi. Water level test

(SNI 3818:2014)

\subsubsection{The Second research}

\subsubsection{The shelf life of the product using the Arrhenius method.}

The drained meatballs were placed in vacuum packaging (20) using the plastic-type NYL15/LDPE60 (75 mic) (21). Subsequently, the product was stored at temperatures of 5 , $15,25,35$, and $45^{\circ} \mathrm{C}$. The tiered stage method and scoring points on a scale of 1-7 were used by trained panelists to observe the damage (22).

$\mathrm{k}=\mathrm{k}_{\mathrm{o}} \cdot \mathrm{e}^{-\mathrm{Ea} / \mathrm{RT}}$

Where:

k: quality loss constant

$\mathrm{k}_{\mathrm{o}}$ : constant (does not depend on the temperature)

e: base logarithm (2.718282)

Ea: activation energy

$\mathrm{T}$ : absolute temperature $\left({ }^{\circ} \mathrm{C}+273\right)$

$\mathrm{R}$ : gas constant, $1,986 \mathrm{cal} / \mathrm{mol}$

The stages of determining shelf life using the ASLT (Accelerated Shelf Life Testing) and Arrhenius method (23):

1. Determine the quality parameters of the test meatballs product and their acceptance status by trained panelists, especially in terms of mucus, and aroma, conduct a storage test at temperatures of $5,15,25,35,45^{\circ} \mathrm{C}$ to accelerate product damage and properly observe quality degradation.

2. Determine the initial quality value (Q0) of the measured parameter. 
3. Measure the product quality damage at every fixed time interval and set the unit of measurement as days.

4. Conduct a sensory evaluation of the test product during the storage test process to measure its acceptance status by trained panelists and obtain a critical quality value (Qc) for the product.

5. Plot the quality parameter measurement data $(y=Q t)$ against time $(x=t)$ and change the data to the form $\ln (y=\ln [Q] t)$.

6. Create a linear regression from the results of plotting quality vs time parameter data, where the determination of zero or one order is seen from the value of the coefficient of determination (R2). The closeness of the reaction to the specified order increases with the value of $R 2$ :

a. If $\mathrm{R} 2$ is higher in the plot where $\mathrm{y}=\mathrm{Qt}$, then the reaction is zero-order; and

b. If $R 2$ is higher in the plot where $y=\ln [Q t]$, then the reaction is first order.

7. From the obtained regression equation, determine the value of $[Q] 0$ or $\ln ([Q] 0)$ and $k$, which refers to the following zero-order equation:

$Y=a-b \cdot x$

$[\mathrm{Q}]_{\mathrm{t}}=[\mathrm{Q}]_{0}-\mathrm{k.t}$

8. Change the value of $k$ obtained to $\ln (k)$ and modify the temperature treatment data $(T)$ to $1 / \mathrm{T}$ (conversion of ${ }^{\circ} \mathrm{C}$ to $\mathrm{K}$ )

9. Plot the data $\ln (k)$ against the temperature treatment $(y=\ln (k), x=1 / T)$ and create a linear regression.

10. Enter the desired temperature data to calculate the value of $k$ after the $\ln \mathrm{k} 0$ and activation energy ( $E$ ) is obtained.

Note: temperature is converted to $\mathrm{K}$ in increments of 273 to the value in degrees Celsius.

Example: $30^{\circ} \mathrm{C}=30^{\circ} \mathrm{C}+273^{\circ} \mathrm{K}=303^{\circ} \mathrm{K}$

11. Enter the formula to find the value of $t s$.

$\mathrm{ts}=(\mathrm{No}-\mathrm{Nt}) / \mathrm{k}$ (for a ordo 0 reaction rate )

$\mathrm{ts}=\ln (\mathrm{No}-\mathrm{Nt}) / \mathrm{k}$ (for a first-ordo reaction rate)

\subsubsection{Sensory evaluation of hedonic test}

The attributes of color, taste, texture, and aroma were assessed by the panelists. Subsequently, the $4 \times 3$ experimental design data with 3 replications was calculated by SPSS using Anova and Duncan's further test.

\section{Results and discussion}

\subsection{First Research}

\subsubsection{Emulsification test}

The protein content of COA cannot be the basis for the emulsification properties of ISP due to the presence of ISP D and E, which are sticky and do not form a chewy texture. Consequently, the emulsifying properties of ISP $B, A$, and $C$ showed the best ratings.

\subsubsection{Meatball Peel Formation test}

The best meatball peels were obtained at $65^{\circ} \mathrm{C}$ during the first boiling. These products had a juicy and crunchy character in every bite unlike those obtained at $75^{\circ} \mathrm{C}$ and $85^{\circ} \mathrm{C}$. This was made evident by the water content test conducted at $65^{\circ} \mathrm{C}, 75^{\circ} \mathrm{C}$, and $85^{\circ} \mathrm{C}$, 
where the percentages of the water stored were $62.88 \%, 54.90 \%$, and $51.70 \%$, respectively.

\subsubsection{Meatball Peel Formation test}

\subsubsection{Inflate Test and Wrinkle Test}

The test results showed that the meatballs without ISP did not inflate and were excessively wrinkled. Meanwhile, the opposite reaction was observed in the products containing this substance, where the best ISP doses in this test were $8 \%, 4 \%$, and $2 \%$.

Table 1 Test of inflating power and wrinkle power

\begin{tabular}{ccccccc}
\hline & \multicolumn{3}{c}{ Inflate power } & \multicolumn{3}{c}{ Wrinkle power } \\
\cline { 2 - 7 } & Dak & Daw & $\%$ & Bak & baw & $\%$ \\
\hline A1B1 & 2 & 2.1 & $5 \%$ & 20 & 17.20 & $-14 \%$ \\
A1B2 & 2 & 2.2 & $10 \%$ & 20 & 18.00 & $-10 \%$ \\
A1B3 & 2 & 2.3 & $15 \%$ & 20 & 18.74 & $-6 \%$ \\
A1B4 & 2 & 2.35 & $18 \%$ & 20 & 19.04 & $-5 \%$ \\
A2B1 & 2 & 2.15 & $8 \%$ & 20 & 17.70 & $-12 \%$ \\
A2B2 & 2 & 2.2 & $10 \%$ & 20 & 18.64 & $-7 \%$ \\
A2B3 & 2 & 2.25 & $13 \%$ & 20 & 19.00 & $-5 \%$ \\
A2B4 & 2 & 2.28 & $14 \%$ & 20 & 19.20 & $-4 \%$ \\
A3B1 & 2 & 2.11 & $5 \%$ & 20 & 17.06 & $-15 \%$ \\
A3B2 & 2 & 2.14 & $7 \%$ & 20 & 17.70 & $-12 \%$ \\
A3B3 & 2 & 2.16 & $8 \%$ & 20 & 18.32 & $-8 \%$ \\
A3B4 & 2 & 2.2 & $10 \%$ & 20 & 18.56 & $-7 \%$ \\
\hline
\end{tabular}

3.1.3.2. Meatball Crack, Texture, and Elasticity Test, and Meatball Moisture Content

The results of the meatball crack and hardness tests using a texture analyzer machine prove the products without ISP crack faster and were very difficult to test due to their hardness. These meatballs had a lower water content value and were proven to save less amount of water (low WHC levels). In addition, these results showed that more water is absorbed as the dose of ISP increased and according to SNI 3818:2014, a good meatball contains a maximum of $70 \%$ water content. Furthermore, products with an $8 \%$ ISP dose did not meet the required standards as $4 \%$ and $2 \%$, which are considered the best in this testing stage. This research was in agreement with a statement by Illanistyas et al., (2021), where the use of ISP was observed to increase WHC levels hence, forming stable emulsification and elastic properties. Also, following the statement by IIma et al., (2019) (24), ISP assists in producing final products with a springy character.

Table 2 crack strength test, texture hardness, elasticity, and water content

\begin{tabular}{ccccc}
\hline Code & Crack Test & Texture Hardness & Elasticity & Water content \\
\hline 324 & 650 & 7,419 & 9 & $51.89 \%$ \\
345 & 690 & 5,722 & 3 & $61.00 \%$ \\
453 & 700 & 7,668 & 8 & $70.55 \%$ \\
567 & 680 & 6,836 & 9 & $73.99 \%$
\end{tabular}




\begin{tabular}{lllcl}
\hline 654 & 690 & 6,483 & 7 & $51.45 \%$ \\
567 & 720 & 5,755 & 5 & $60.02 \%$ \\
876 & 730 & 7,640 & 9 & $70.89 \%$ \\
455 & 700 & 4,403 & 12 & $71.00 \%$ \\
433 & 600 & 7,870 & 15 & $51.97 \%$ \\
233 & 630 & 6,139 & 9 & $61.55 \%$ \\
345 & 620 & 6,482 & 9 & $70.89 \%$ \\
432 & 610 & 5,384 & 15 & $74.69 \%$ \\
\hline
\end{tabular}

3.2. Second Research

\subsubsection{Shelf Life Test}

After assessing the results from trained panelists, the tiered stage shelf-life test data was inputted into the Arrhenius method to obtain the equations shown in Table 3.

\begin{tabular}{cc} 
Table 3 Arrhenius equation for each product \\
\hline Code & Arrhenius Equation \\
\hline A1B1 & $y=-14504 x+47.015 R^{2}=0.8926$ \\
A1B2 & $y=-14121 x+45.75 R^{2}=0.8738$ \\
A1B3 & $y=-13639 x+44.192 R^{2}=0.8693$ \\
A1B4 & $y=-13571 x+43.979 R^{2}=0.8745$ \\
A2B1 & $y=-14504 x+47.015 R^{2}=0.8926$ \\
A2B2 & $y=-12960 x+41.491 R^{2}=0.8494$ \\
A2B3 & $y=-13352 x+42.957 R^{2}=0.8167$ \\
A2B4 & $y=-13571 x+43.979 R^{2}=0.8745$ \\
A3B1 & $y=-14504 x+47.015 R^{2}=0.8926$ \\
A3B2 & $y=-14121 x+45.75 R^{2}=0.8738$ \\
A3B3 & $y=-13639 x+44.192 R^{2}=0.8693$ \\
A3B4 & $y=-14487 x+47.242 R^{2}=0.8373$
\end{tabular}

The table of average shelf life was presented in Table 4 and Figure 2.

Table 4 Average shelf life of products using the Arrhenius method

\begin{tabular}{clcc}
$\begin{array}{c}\text { Product } \\
\text { Code }\end{array}$ & \multicolumn{1}{c}{ Time and Temperature } & Long Shelf Life & $\begin{array}{c}\text { Average } \\
\text { Shelf Life / } \\
\text { Dayi }\end{array}$ \\
\hline \multirow{2}{*}{ A1B1 } & Average morning temperature $22^{\circ} \mathrm{C}$ & 4.81 day & \\
& Average daytime temperature $35^{\circ} \mathrm{C}$ & 0.6 day & 3.41 day \\
& Average night temperature $25^{\circ} \mathrm{C}$ & 4.81 day & \\
& Average morning temperature $22^{\circ} \mathrm{C}$ & 4.65 day & \\
A1B2 & Average daytime temperature $35^{\circ} \mathrm{C}$ & 0.62 day & 3.31 day \\
& Average night temperature $25^{\circ} \mathrm{C}$ & 4.65 day & \\
& Average morning temperature $22^{\circ} \mathrm{C}$ & 4.31 day & \\
A1B3 & Average daytime temperature $35^{\circ} \mathrm{C}$ & 0.61 day & 3.08 day \\
& Average night temperature $25^{\circ} \mathrm{C}$ & 4.31 day & \\
A1B4 & Average morning temperature $22^{\circ} \mathrm{C}$ & 4.24 day & 3.03 day \\
& Average daytime temperature $35^{\circ} \mathrm{C}$ & 0.61 day &
\end{tabular}


Average night temperature $25^{\circ} \mathrm{C}$

Average morning temperature $22^{\circ} \mathrm{C}$

A2B1 Average daytime temperature $35^{\circ} \mathrm{C}$

Average night temperature $25^{\circ} \mathrm{C}$

Average morning temperature $22^{\circ} \mathrm{C}$

A2B2 Average daytime temperature $35^{\circ} \mathrm{C}$

Average night temperature $25^{\circ} \mathrm{C}$

Average morning temperature $22^{\circ} \mathrm{C}$

A2B3 Average daytime temperature $35^{\circ} \mathrm{C}$

Average night temperature $25^{\circ} \mathrm{C}$

Average morning temperature $22^{\circ} \mathrm{C}$

A2B4 Average daytime temperature $35^{\circ} \mathrm{C}$

Average night temperature $25^{\circ} \mathrm{C}$

Average morning temperature $22^{\circ} \mathrm{C}$

A3B1 Average daytime temperature $35^{\circ} \mathrm{C}$

Average night temperature $25^{\circ} \mathrm{C}$

Average morning temperature $22^{\circ} \mathrm{C}$

A3B2 Average daytime temperature $35^{\circ} \mathrm{C}$

Average night temperature $25^{\circ} \mathrm{C}$

Average morning temperature $22^{\circ} \mathrm{C}$

A3B3 Average daytime temperature $35^{\circ} \mathrm{C}$

Average night temperature $25^{\circ} \mathrm{C}$

Average morning temperature $22^{\circ} \mathrm{C}$

A3B4 Average daytime temperature $35^{\circ} \mathrm{C}$

Average night temperature $25^{\circ} \mathrm{C}$
4.24 day

4.81 day

0.6 day

4.81 day

6.43 day

1.01 day

6.43 day

5.6 day

0.83 day

5.6 day

4.24 day

0.61 day

4.24 day

4.81 day

0.6 day

4.81 day

4.65 day

0.62 day

4.65 day

4.31 day

0.61 day

4.31 day

3.62 day

0.46 day

3.62 day
3.41 day

3.41 day

4.62 day

4.01 day

3.03 day

3.31 day

3.08 day

2.56 day

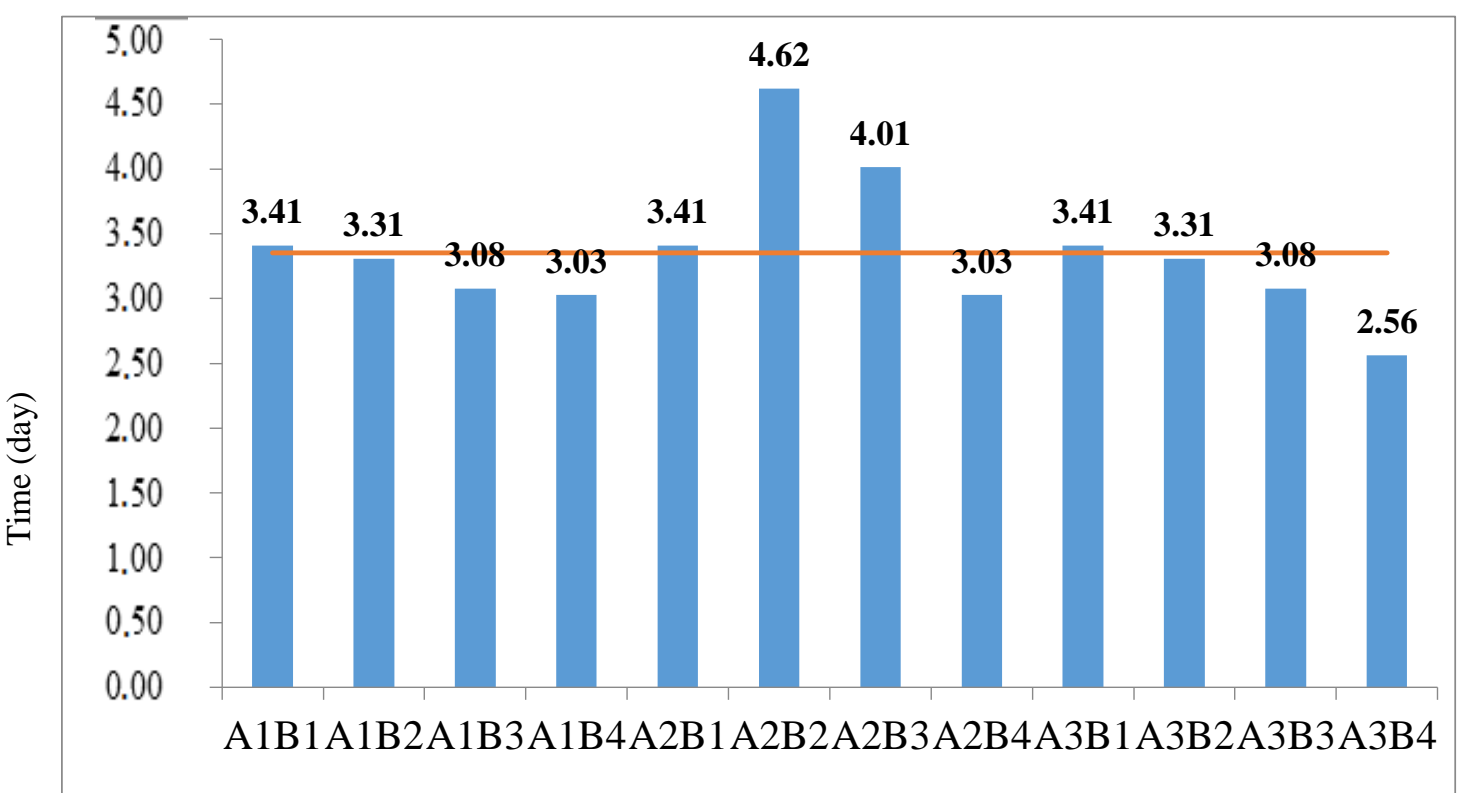

Code of product

Figure 2 The longest shelf life of A2B2 meatballs 
The results showed A2B2 meatballs had a longer shelf life compared to other products. This is interesting because it agrees with the results, which show the emulsion stability of the products has an inverse relationship with the added ISP concentration (Kharisma et al., 2016). The decrease in stability caused the emulsion in the final product to decompose and expel its water content. In addition, the use of ISP has been shown to increase WHC in processed meat products (25).

\subsubsection{Sensory Evaluation Test}

The analysis results using SPSS with Anova and Duncan's tests showed A2B2 meatballs had the best aroma, taste, texture, and color as shown in the descriptions of the hedonic taste test data processing:

\subsubsection{Sensory results taste evaluation}

A distinctive and savory meatball taste with the right amount of salt, proper mouthfeel, and without a deviant or bitter aftertaste on the palate was obtained from the twelve trained panelists. Meanwhile, a tastier product was acquired from the use of an ISP, which agrees with Putri's 2018 statement (26).

\subsubsection{Sensory results texture evaluation}

The meatball texture obtained from the twelve trained panelists was unique, chewy, dense, crunchy, and juicy but not mushy or hard (medium texture) because of its water holding capacity. These properties were different from the other eleven products.

\subsubsection{Sensory results color evaluation}

The typical distinct meatball color was obtained from the twelve trained panelists.

\subsubsection{Sensory results aroma evaluation}

The aroma was distinctive with the absence of a distorted scent or smell.

\section{Conclusions}

The OE and PG methods were used to test the emulsification properties of ISP raw materials, where checking COA were insufficient. Meanwhile, the A2B2 meatball formulation was considered the best with an ISP dose of $2 \%$, which was added dry at the first boiling temperature of $65^{\circ} \mathrm{C}$. Therefore, ISP can serve as a substitute for meat because it results in a more stable meatball quality, with a longer shelf life, a juicy, crispy, and tasty product enjoyed by consumers.

\section{References}

1. Sinaga DD, Herpandi H, Nopianti R. Karakterisitik bakso Ikan Patin (Pangasius pangasius) dengan penambahan karagenan, isolat protein kedelai, dan Sodium Tripolyphospat. J Teknol Has Perikan. 2016;6(1):1-13.

2. Nasution Z, Ilza M, Sari NI. Study Vacuum and Non Vacuum Packaging on the Quality of Fish Balls Malong (Muarenesox Talabon) During Cold Storage Temperature $( \pm 50 \mathrm{c}$ ). Riau University; 2016.

3. Saputrayadi A, Asmawati A, Marianah M, Suwati S. Analisis Kandungan Boraks dan Formalin Pada Beberapa Pedagang Bakso di Kota Mataram. J Agrotek Ummat. 2019;5(2):107-16. 
4. Falahudin A. Kajian Kekenyalan dan Kandungan Protein Bakso Menggunakan Campuran Daging Sapi Dengan Tepung Jamur Tiram Putih (Pleurotus ostreatus). Agrivet J Ilmu-IImu Pertan dan Peternak (Journal Agric Sci Veteriner). 2013;1(2).

5. Astati A. Tingkat perubahan kualitas bakso daging sapi bali bagian sandurng lamur (Pectoralis profundus) selama penyimpaan dengan pemberian asap cair. TEKNOSAINS MEDIA Inf SAINS DAN Teknol. 2013;7(1):10-9.

6. Hayati R, Marliah A, Rosita F. Sifat kimia dan evaluasi sensori bubuk kopi arabika. J Floratek. 2012;7(1):66-75.

7. Pamungkas MC, Probowati BD, Maflahah I. Pengukuran preferensi konsumen bakso. AGROINTEK. 2014;8(1):32-9.

8. Sofiana A. Penambahan tepung protein kedelai sebagai pengikat pada sosis sapi. J IIm Ilmu-IImu Peternak. 2012;15(1):1-7.

9. Astawan M, Prayudani APG. The Overview of Food Technology to Process Soy Protein Isolate and Its Application toward Food Industry. World Nutr J. 2020;4(1-1):12-7.

10. Hatta M, Murpiningrum E. Kualitas Bakso Daging Sapi dengan Penambahan Garam (NaCl) Dan Fosfat (Sodium Tripolifosfat/STPP) pada Level dan Waktu yang Bebeda. JITP. 2012;2(1):30-8.

11. S N, IW W, AA W. Pengaruh penambahan Sodium Tripolifosfat (STPP) terhadap karakteristik pati Sente (Alocasia Macrorrhiza) yang dimodifikasi dengan metode Cross-Linking. J ITEPA. 2016;5(2):103-11.

12. AP $C, L M, T W, M$ A. Perbandingan karakteristik fisikokimia dan komposisi asam amino tepung tempe larut air dengan isolat protein kedelai komersial. J Pangan. 2020;29(1):45-54.

13. $\mathrm{R} A, A C A$. Pengaruh subsitusi tempe dan penambahan isolat soy protein terhadap mutu organoleptik dan kandungan sosis ayam. Media Gizi Indones. 2016;11(1):80-7.

14. Lekahena VNJ. Pengaruh Penambahan Konsentrasi Tepung Tapioka Terhadap Komposisi Gizi dan Evaluasi Sensori Nugget Daging Merah Ikan Madidihang. Agrikan J Agribisnis Perikan. 2016;9(1):1-8.

15. Nugraha EP, Karyantina M, Kurniawati L. Sodium Tripolyphosphate (STPP) Sebagai bahan Pengganti Bleng Padat Pada Pembuatan Karak Dengan Variasi jenis Beras. JITIPARI (Jurnal IIm Teknol dan Ind Pangan UNISRI). 2017;1(2).

16. Sari HA, Widjanarko SB. Karakteristik kimia bakso sapi (Kajian proporsi tepung tapioka: tepung porang dan penambahan. J Pangan dan Agroindustri. 2014;3(3).

17. Wijaya W. Penyusunan Standard Operational Procedure Produksi Pada Bisnis Bakso Pepo. PERFORMA J Manaj dan Start-Up Bisnis. 2016;1(1):69-76.

18. Muhammad I, Rusgiyono A, Mukid MA. Penilaian Cara Mengajar Menggunakan Rancangan Acak Lengkap (Studi Kasus: Cara Mengajar Dosen Jurusan Statistika Undip). J Gaussian. 2014;3(2):183-92.

19. Diana C, Dihansih E, Kardaya2a D. Kualitas fisik dan kimiawi daging sapi beku pada berbagai metode Thawing Physical and Chemical.

20. Nasaruddin M, Utama SP, Andani A. Nilai Tambah Pengolahan Daging Sapi Menjadi Bakso pada USAha Al-hasanah di Kelurahan Rimbo Kedui Kecamatan Seluma Selatan. J AGRISEP Kaji Masal Sos Ekon Pertan dan Agribisnis. 2015;14(1):85-96.

21. Candra RM, Sucita D. Sistem Pakar Penentuan Jenis Plastik Berdasarkan Sifat Plastik Terhadap Makanan yang akan Dikemas Menggunakan Metode Certainty Factor (Studi Kasus: CV. Minapack Pekanbaru). J CorelT J Has Penelit Ilmu Komput dan Teknol Inf. 2015;1(2):77-85. 
22. Amalia U. Pendugaan umur simpan produk nugget ikan dengan merk dagang fish nugget "So Lite". J Saintek Perikan. 2012;8(1):27-31.

23. Arif. Metode Accelarated Shelf Life Testing (ASLT) dengan pendekatan arrhenius dalam pendugaan umur simpan sari buah nanas, pepaya dan cempedak. J Inform Pertan. 2016;25(2):189-98.

24. Ilma PRA, Nocianitri KA, Hapsari NMI. Pengaruh penambahan isolat protein kedelai terhadap karakteristik kamaboko Ikan Barramundi (Lates calcalifer). J Ilmu dan Teknol Pangan. 8(3):313-22.

25. M A, AP P, NA R. Isolat protein teknik produksi, sifat - sifat fungsional, dan aplikasinya di industri pangan. Bogor: IPB press. Bogor; 2020. 99-109 bl.

26. Putri WAM, Agrippina FD. Pengaruh Substitusi Isolat Dan Konsentrat Protein Kedelai Terhadap Sifat Kimia Dan Sensoris Sosis Daging Ayam. Maj TEGI. 2018;10(1). 